\title{
The Impact of Ketogenic Diet on Colorectal Cancer Progression and the Co-evolution of Gut Microbiota: A Research Protocol
}

\author{
Melika Shirdarreh, HBSc [1]*, Yasamin Sadeghi, HBSc [2], Tina Rahimi, BSc [3] \\ All authors contributed equally.
}

[1] Department of Immunology, University of Toronto, Toronto, Ontario, Canada

[2] Department of Biological Sciences, University of Toronto Scarborough, Toronto, Ontario, Canada

[3] Department of Genetics, Islamic Azad University of Tehran, Tehran, Iran

*Corresponding Author: melika.shirdarreh@mail.utoronto.ca

\begin{abstract}
Introduction: To date, the ketogenic diet (KD) has been shown to improve certain health conditions such as seizure. These positive effects have been partly mediated through the gut microbiome. However, research on KD's impact on colorectal cancer (CRC) and the gut microbiome of cancer patients that use KD has been scant. This study aims to investigate the role of $\mathrm{KD}$ in the co-evolution of gut microbial composition and CRC progression. We hypothesize that KD alters overall species diversity through either elimination of harmful bacterial genera or perpetuation of beneficial gut microbiota which could ultimately be the mechanism underlying positive CRC outcomes.

Methods: In order to test this hypothesis, we propose a murine study using $A p c^{M i n /+}$ (multiple intestinal neoplasia) CRC mouse models in C57BL/6J background. The mice will either be given normal chow (control group) or KD (87\% fat) for 8 weeks. Mice will be euthanized at the end of the experiment and analyzed in terms of polyp size and polyp number in the small intestine and colon. Frozen colon tissue will also be used to extract mRNA for quantitative polymerase chain reaction (qPCR) analysis of TH17 cytokine production. Gut microbiome composition will be analyzed by sequencing of 16S rRNA genes. To compare microbiome structure between diet groups, alpha diversity will be used to measure the differences in gut microbial structure in the control and experimental groups.

Results: We would expect that mice fed a KD would have altered microbiota diversity, a decreased level of cytokine production, as well as fewer and smaller polyps (as measured in the small intestine and colon).

Discussion: Analysis of the gut microbiota post-treatment, in conjunction with assessment of cytokine levels will help to set correlations between microbial gut activity and CRC progression.

Conclusion: The results of this experiment could give insight into the impact of KD on development and progression of $\mathrm{CRC}$; which could be used to develop therapeutic or dietary interventions.
\end{abstract}

Keywords: ketogenic diet; colorectal cancer; microbiome; alpha diversity; beta diversity

\section{Introduction}

The low carbohydrate, high fat ketogenic diet (KD) has recently become popular mainly for its effect in weight loss. Further roles of this diet in treatment of pathologies such as refractory epilepsy have also been explored. In a $\mathrm{KD}$, carbohydrate consumption is dramatically reduced and is replaced with more fat consumption without changing the total calorie intake. This causes the body to digest fats as the primary energy source and thus produce ketone bodies as a by-product [1]. Ketone bodies have been shown to selectively inhibit Bifidobacterium growth and also reduce the number of TH17 proinflammatory T cells [2]. KD has also been shown to have promising therapeutic benefits for colorectal cancer (CRC) patients [3]. More precisely, combining a KD with standard chemotherapeutic and radiotherapeutic options may help to improve tumor response. Cancer has recently been regarded as a metabolic disease, and studies have started to examine metabolic therapy using $\mathrm{KD}$ as a complementary or alternative therapy for cancer [4]. Since KD switches the cellular energy source from glucose to fatty acids and ketone bodies, it is suitable for the dietary management of specific metabolic disorders [4]. KD has been prescribed since the 1920 s to treat refractory epileptic seizures in children. The majority of previous studies on the anti-tumor effects of KD have focused on specific types of cancer including brain, 
UNDERGRADUATE RESEARCH IN NATURAL AND CLINICAL SCIENCE AND TECHNOLOGY (URNCST) JOURNAL Read more URNCST Journal articles and submit your own today at: https://www.urncst.com

prostate, and breast cancers. Few studies have addressed such effects on CRC [3].

Since diet can alter the composition of the gut microbiome, dietary therapy has been shown to have a positive impact on a wide range of conditions [5]. Recent studies have found the gut microbiome to be a crucial modulator of the neuroprotective mechanism of $\mathrm{KD}$ in epilepsy [6]. However, more research is needed on the effects of KD administration and the possible role of gut microbiota as mediators in other diseases, such as cancer. A $\mathrm{KD}$ can lower inflammation in the gut and alter the microbiota profile, shifting it towards a healthier composition [3]. It remains to be explored whether KD can decrease harmful, disease-associated bacteria, such as Fusobacterium (Fusobacteriaceae) and Porphyromonas (Porphyromonadaceae). Thus far, it has been found that these two genera of bacteria were highly enriched in the intestinal microbiome profiles of CRC patients. The production of hydrogen sulfide by Fusobacterium was reported to be one likely contributing factor to CRC development [7].

In this study, we ask whether cytokine production, intestinal length, intestinal polyp number and polyp size will be influenced by administration of $\mathrm{KD}$ to mice. Concurrently, we will assess microbial gut profiles of mice in both diet groups for the purpose of: 1) general comparison of species abundance and 2) observing whether harmful bacteria, namely Fusobacterium (Fusobacteriaceae) and Porphyromonas (Porphyromonadaceae) will decrease over several weeks [7].

\section{Methods}

Animal Models

We will be using $A p c^{\mathrm{Min} /+}$ (multiple intestinal neoplasia) mice on $\mathrm{C} 57 \mathrm{BL} / 6 \mathrm{~J}$ background as $\mathrm{CRC}$ mouse models. $A p c^{\text {Min+/ }}$ mice carry a nonsense mutation in exon 15 of Adenomatous Polyposis Coli (Apc) tumor suppressor gene. This loss-of-function mutation results in development of multiple polyps in the colon and small intestine [8]. Pathogen contamination from the surrounding environment will be prevented through containment of mice in clean housing facilities, such as in specific-pathogen-free conditions.

\section{Study Design}

Control the experiment starts 4 weeks after the mice are born which is when they are fully weaned from their mother and begin eating solid food. The control group will receive a standard rodent diet while the $\mathrm{KD}$ group will receive $\mathrm{KD}$. Control diet contains $64 \%$ carbohydrates, $20 \%$ protein, $16 \%$ fat while the KD contains $5 \%$ carbohydrates, $8 \%$ protein, $87 \%$ fat [3]. Mice in both groups are going to be fed respective diet regimens for 8 weeks. After 8 weeks mice in both groups will be euthanized to analyze gut microbiota diversity, inflammatory cytokine production, polyp size and polyp number. Approximately $1 \mathrm{~cm}$ snips of colon will also be taken and snap frozen for mRNA extraction (Figure 1).

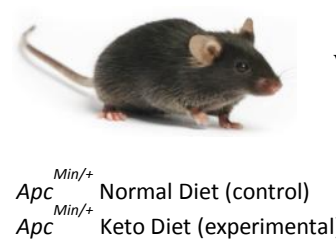

Figure 1. Schematic diagram showing the experimental design for CRC. Week 0 denotes the start of the experiment which is when the mice are 4 weeks old and fully weaned. Fecal sample will be collected at weeks $0,2,4$, and 6 of the experiment. The mice will be sacrificed after 8 weeks from the start of the experiment and analyzed for caecum weight, intestinal length, polyp number and size in small intestine and colon. Fecal samples will also be collected at the end of experiment ( 8 weeks) and colon tissue will be frozen for mRNA extraction.

Gut Microbiota Profiling

Gut microbial diversity profiles will be generated from fecal samples taken from both control and experimental groups this will be done every 2 weeks (during weeks $0,2,4,6$, and 8) until the end of the dietary regimen period. Fecal samples will be frozen immediately at $-80^{\circ} \mathrm{C}$.

\section{DNA Extraction}

Stool samples $(80-150 \mathrm{mg}$ ) will be collected from each cohort (normal vs KD) shortly prior to euthanization.
Collected samples will be pre-processed with phosphate buffered saline (PBS) containing lysozyme and mutanolysin. Genomic DNA will be extracted using NucleoSpin Soil kit (following the manufacturer's protocol).

Polymerase Chain Reaction (PCR) Assessment of Bacterial Loads \& 16S rRNA Sequencing and Analysis

The V4-V5 hypervariable regions of the 16S rRNA genes (Figure 2) will be amplified using the following 
UNDERGRADUATE RESEARCH IN NATURAL AND CLINICAL SCIENCE AND TECHNOLOGY (URNCST) JOURNAL Read more URNCST Journal articles and submit your own today at: $\underline{\text { https://www.urncst.com }}$

primer pairs: forward primer (5'-AYTGGGYDTAAAGNG$3^{\prime}$ ), reverse primer (3'-TGARTTTMCTTAACTGCC-5') [9]. Briefly, duplicate PCR reactions with 25 cycles of amplification will be used at $95{ }^{\circ} \mathrm{C}$ for $20 \mathrm{~s}, 40{ }^{\circ} \mathrm{C}$ for $30 \mathrm{~s}$, and $72{ }^{\circ} \mathrm{C}$ for $20 \mathrm{~s}$. Samples will be purified, quantified and subsequently pooled at equimolar concentrations.

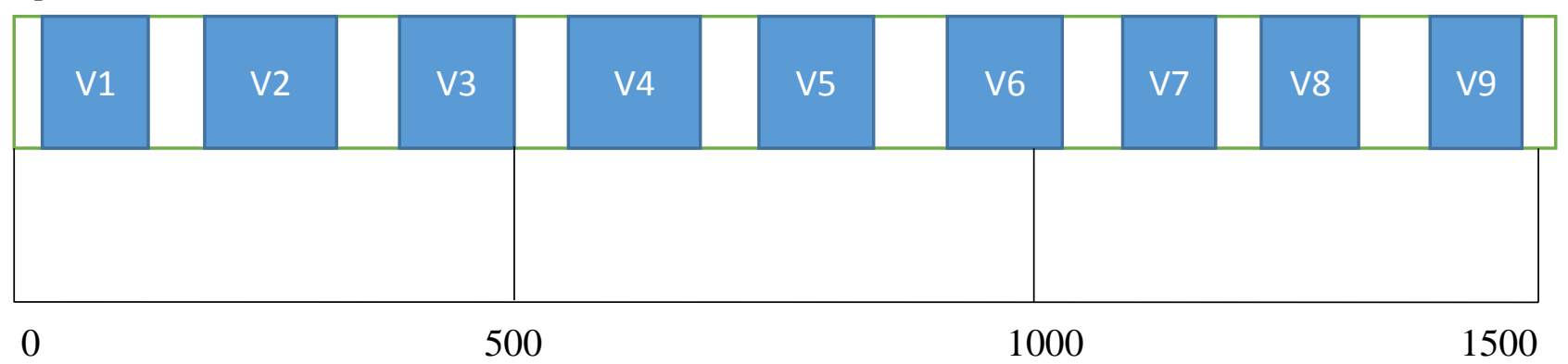

Length in base pair (bp)

Figure 2. 16S rRNA gene ( 1,540 kb) of E. coli showing variable regions v1-v9, which allow for the ability to distinguish between different microorganisms.

Next, Illumina MiSeq high-throughput sequencing will be performed with $2 \mathrm{X} 300 \mathrm{PE}$ configuration. After receiving raw data, $16 \mathrm{~S}$ rRNA sequences will be demultiplexed using QIIME v.1.9.1 [10]. DNA barcodes will be assembled and primers will be removed. As a last step in quality control of sequences, chimera removal will be processed via SILVA reference set of 16 S sequences. Filtered and trimmed sequences will be clustered into Operational-Taxonomic-Units (OTUs) based on a 97\% threshold of pairwise identity for bacterial species as compared to the Greengenes reference database [11]. The Operational-Taxonomic-Unit (OTU) will be selected via normalizing a subset of 25,000 randomly selected sequences, using the uclust algorithm [12]. Following OTU picking, diversity analysis will be performed. Diversity parameters and alpha diversity indexes such as Chao's and Shannon's evenness will be calculated using Mothur v.137.

\section{Statistical Comparisons of Species Diversity}

Both alpha and beta diversity will be adopted in analysis of 16S rRNA amplicons, though for different purposes. Alpha diversity indicates the number of taxa (richness) or relative abundance of taxa (evenness) in a select habitat. Beta diversity assess differences in microbial communities (identity of taxa) between two different habitats [13]. In other words, while alpha diversity serves as summary statistics of a single population, the beta diversity acts as a similarity score between populations. To accomplish our assessment of global structural changes in the gut microbiota communities, we plan to use permutation-based multivariate analysis of variance. To this end, beta diversity based on Bray-Curtis dissimilarity index will be used to attain distance among samples and groups in the microbial gut structure. Information from those OTUs that indicate varied abundance $(\mathrm{p}<0.05)$ will be chosen for further analysis via the Pairwise Wilcoxon Rank Sum test with post hoc Bonferroni test [14]. The aforementioned approaches will assist with comparing sample pairs and alpha diversity (overall bacterial species richness) between groups.

Measuring Cytokines, Polyp Number and Polyp Size

All mice will be weighted and humanely euthanized by $\mathrm{CO} 2$ asphyxiation 8 weeks after the start of the experiment and subsequent cervical dislocation and will be analyzed for the number of polyps in small intestine and colon, intestinal length and caecum weight. After termination, the intestinal tract will be isolated for polyp number and size (diameter). The intestinal tract will be rinsed with PBS opened along the longitudinal axis. Polyp count will start from duodenum and proceeds towards colon. Polyps will be counted and analyzed for diameter at X20 magnification under dissecting microscope [15]. For cytokine measurement, total RNA will be extracted from colonic tissues using TRIzol®. $1 \mu \mathrm{g}$ of DNA-free RNA will be used for cDNA synthesis. Quantitative PCR (qPCR) will then be performed using SYBR Green Supermix to investigate the gene expression of TH17 cytokines, notably, interleukin (IL)-17A, IL-17F, IL-21, and IL-22 using appropriate specific primers. The specific primer pairs are as follows: IL-17A forward (5'-ACCAATCCCAAAAGGTCC TC-3'), IL-17A reverse (3' -CACTTTGCCTCCCAGATCA C-5') [16], IL-17F forward (5'-CTGAGGCCCAGTGCA GACA-3'), IL-17F reverse (3' -TTGAGGCAGCGGTAAG TCG-5') [17], IL-21 forward (5'-TCAGCTCCACAAGA TGTAAAG GG-3'), IL-21 reverse (3'-TAGTAACTGG AGCACCGGG-5') [18], IL-22 forward (5'-TTGAGGTGT CCAACTTCCAGCA-3'), and IL-22 reverse (3'-ATTGTT GTGTCTGCAGGCCGA-5') [19]. Relative fold gene expressions will be determined. 
UNDERGRADUATE RESEARCH IN NATURAL AND CLINICAL SCIENCE AND TECHNOLOGY (URNCST) JOURNAL Read more URNCST Journal articles and submit your own today at: https://www.urncst.com

$\underline{\text { Statistical Analysis }}$

Statistical significance will be evaluated using GraphPad Prism V.8. Results will be expressed as means +/- SEM. Kruskal-Wallis one-way ANOVA followed by Dunn's post hoc for multiple comparisons will be used for statistical analysis. P-values $<0.05$ will be considered significant.

\section{Results}

After 8 weeks, tumour number and size in the small intestine and colon will be analyzed to assess tumor progression. The level of expression of inflammatory cytokines will also be recorded using qPCR. We anticipate a decrease in tumor development and progression in mice that received a KD as opposed to regular diet. This decrease can also be confirmed through qPCR results as decline in the level of inflammatory cytokines is also an indication of tumor management and CRC improvement. It is expected that improved inflammatory outcome will be correlated with a decrease of bacterial of genera abundant in CRC samples, namely Fusobacterium (Fusobacteriaceae) and Porphyromonas (Porphyromonadaceae).

\section{Discussion}

The results will be used to compare CRC outcomes in mice treated with a ketogenic formula compared to mice on regular diet. As with any study, there are a few limitations to consider. Firstly, this study is limited to the species under study. As the microbial community in mice is different from that of humans'[20], the results of this experiment cannot be immediately translated to human subjects. As well, 16S rRNA sequencing is a technique riddled with limitations such as PCR amplification biases, overinflation of diversity estimates and low resolution of the 16S rRNA gene [21]. Therefore, more comprehensive functional analyses might help in better determining closely related species in studies of the gut microbiome. Furthermore, studies have shown that mice with humanized gut microbiomes are unable to recapitulate full infection responses [22]. This elucidates the complex interactions between the gut environment and disease, which cannot be decisively summarized through correlational studies. Further investigations that explore the mechanistic interplay of $\mathrm{KD}$ and the microbiota in CRC are required.

\section{Conclusions}

Through proposing this experiment, we aim to introduce keto microbiota as modulators of cancer progression and/or chemotherapeutic response; while simultaneously observing immunologic responses and rate of tumor development in mice on KD. Relative contribution of the microbiome and dietary components to CRC phenotypes are multifaceted and nuanced. The KD can exert its effect on cancer progression through various mechanisms, of which only one was explored in this study.
Thus, other mechanisms such as KD's effect on gene expression are worthy of pursuit.

\section{List of Abbreviations Used}

APC: adenomatous polyposis coli

CRC: colorectal cancer

IL: interleukin

KD: ketogenic diet

OUT: operational-taxonomic-unit

PBS: phosphate buffered saline

PCR: polymerase chain reaction

qPCR: quantitative PCR

QIIME: quantitative insights into microbial ecology

rRNA: ribosomal RNA

\section{Conflicts of Interest}

The authors report no conflicts of interest.

\section{Ethics Approval and/or Participant Consent}

All article types: All experimental animal procedures will be seeking approval from the University of Toronto University Animal Care Committee (UACC). All work will conform with the Canadian Council on Animal Care (CCAC) and Animals for Research Act standards and guidelines.

\section{Authors' Contributions}

MS contributed to the design of the study, revision, and planning, and drafted the manuscript.

YS contributed to the design of the study, revision, and planning, and drafted the manuscript.

TR contributed to the design of the study, revision, and planning, and drafted the manuscript.

\section{Acknowledgements}

We would like to thank and acknowledge the support provided by Dr. Eliana Gonzales-Vigil at the University of Toronto Scarborough in proofreading a segment of the methods section.

\section{Funding}

None.

\section{References}

[1] Erickson N, Boscheri A, Linke B, Huebner J. Systematic review: isocaloric ketogenic dietary regimes for cancer patients. Med Oncol. 2017 May;34(5):72. https://doi.org/10.1007/s12032-017-0930-5

[2] Ang QY, Alexander M, Newman JC, Tian Y, Cai J, Upadhyay V, et al. Ketogenic Diets Alter the Gut Microbiome Resulting in Decreased Intestinal Th17 Cells. Cell. 2020 Jun;181(6):1263-1275.e16. https://doi.org/10.1016/j.cell.2020.04.027

[3] Kentaro N, Hidekazu T, Akina S, Kinya A. A Ketogenic Formula Prevents Tumor Progression and 
UNDERGRADUATE RESEARCH IN NATURAL AND CLINICAL SCIENCE AND TECHNOLOGY (URNCST) JOURNAL Read more URNCST Journal articles and submit your own today at: https://www.urncst.com

Cancer Cachexia by Attenuating Systemic Inflammation in Colon 26 Tumor-Bearing Mice. Nutrients. $\quad 2018 \quad$ Feb $14 ; 10(2): 206$. https://doi.org/10.3390/nu10020206

[4] Aminzadeh-Gohari S, Feichtinger RG, Vidali S, Rutherford T, O’Donnel M, Stöger-Kleiber A, et al. A $\mathrm{KD}$ supplemented with medium-chain triglycerides enhances the anti-tumor and anti-angiogenic efficacy of chemotherapy on neuroblastoma xenografts in a CD1-nu mouse. :17. https://doi.org/10.18632/ oncotarget.20041

[5] Zmora N, Suez J, Elinav E. You are what you eat: diet, health and the gut microbiota. Nat Rev Gastroenterol Hepatol. 2019 Jan;16(1):35-56. https://doi.org/10.1038/ s41575-018-0061-2

[6] Lindefeldt M, Eng A, Darban H, Bjerkner A, Zetterström CK, Allander T, et al. The KD influences taxonomic and functional composition of the gut microbiota in children with severe epilepsy. npj Biofilms Microbiomes. 2019 Dec;5(1):5. https://doi.org/10 .1038/s41522-018-0073-2

[7] Ai D, Pan H, Li X, Gao Y, Liu G, Xia LC. Identifying Gut Microbiota Associated With Colorectal Cancer Using a Zero-Inflated Lognormal Model. Front Microbiol. 2019 Apr 24;10:826. https://doi.org/10.3389/ fmicb.2019.00826

[8] Belcheva A, Irrazabal T, Robertson SJ, Streutker C, Maughan H, Rubino $S$, et al. Gut Microbial Metabolism Drives Transformation of Msh2-Deficient Colon Epithelial Cells. Cell. 2014 Jul;158(2):288-99. https://doi.org/10.1016/j.cell.2014.04.051

[9] Klindworth A, Pruesse E, Schweer T, Peplies J, Quast C, Horn M, et al. Evaluation of general 16S ribosomal RNA gene PCR primers for classical and nextgeneration sequencing-based diversity studies. Nucleic Acids Research. 2013 Jan 1;41(1):e1-e1. https://doi.org/10.1093/nar/gks808

[10] Torres PJ, Skarra DV, Ho BS, Sau L, Anvar AR, Kelley ST, et al. Letrozole treatment of adult female mice results in a similar reproductive phenotype but distinct changes in metabolism and the gut microbiome compared to pubertal mice. BMC Microbiol. 2019 Dec;19(1):57. $\quad$ https://doi.org/10.1186/s12866-019$\underline{1425-7}$

[11] McDonald D, Price MN, Goodrich J, Nawrocki EP, DeSantis TZ, Probst A, et al. An improved Greengenes taxonomy with explicit ranks for ecological and evolutionary analyses of bacteria and archaea. ISME J. 2012 Mar;6(3):610-8. https://doi.org/10.1038/ismej .2011 .139

[12] Edgar RC. Search and clustering orders of magnitude faster than BLAST. Bioinformatics. 2010 Oct 1;26(19):2460-1. https://doi.org/10.1093/bioinformatics/ $\underline{\text { btq } 461}$
[13] Walters KE, Martiny JBH. Alpha-, beta-, and gammadiversity of bacteria varies across habitats. PLOS ONE. 2020; 15(9): e0233872. https://doi.org/10.1371/journal .pone. 0233872

[14] Moya-Pérez A, Perez-Villalba A, Benítez-Páez A, Campillo I, Sanz Y. Bifidobacterium CECT 7765 modulates early stress-induced immune, neuroendocrine and behavioral alterations in mice. Brain, Behavior, and Immunity. 2017 Oct;65:43-56. https://doi.org/10.1016/j.bbi.2017.05.011

[15] Yekkala K, Baudino TA. Inhibition of intestinal polyposis with reduced angiogenesis in ApcMin/+ mice due to decreases in c-Myc expression. Mol Cancer Res. 2007 Dec;5(12):1296-303. https://doi.org/10.1158/ 1541-7786.MCR-07-0232

[16] Rauen T, Hedrich CM, Juang YT, Tenbrock K, Tsokos GC. cAMP-responsive element modulator (CREM) $\alpha$ protein induces interleukin 17A expression and mediates epigenetic alterations at the interleukin-17A gene locus in patients with systemic lupus erythematosus. J Biol Chem. 2011 Dec 16;286(50):43437-46. https://doi.org/ 10.1074/jbc.M111.299313

[17] Wu Q, Martin RJ, Rino JG, Breed R, Torres RM, Chu HW. IL-23-dependent IL-17 production is essential in neutrophil recruitment and activity in mouse lung defense against respiratory Mycoplasma pneumoniae infection. Microbes Infect. 2007 Jan;9(1):78-86. https://doi.org/10.1016/j.micinf.2006.10.012

[18] Chen G, Hardy K, Bunting K, Daley S, Ma L, Shannon MF. Regulation of the IL-21 gene by the NF- $\kappa B$ transcription factor c-Rel. J Immunol. 2010 Aug 15;185(4):2350-9. https://doi.org/10.4049/jimmunol .1000317

[19] Kreymborg K, Etzensperger R, Dumoutier L, Haak S, Rebollo A, Buch T, Heppner FL, Renauld JC, Becher B. IL-22 is expressed by Th17 cells in an IL-23-dependent fashion, but not required for the development of autoimmune encephalomyelitis. J Immunol. 2007 Dec 15;179(12):8098-104. https://doi.org/10.4049/jimmunol .179 .12 .8098

[20] Nguyen TLA, Vieira-Silva S, Liston A, Raes J. How informative is the mouse for human gut microbiota research? Disease Models \& Mechanisms. 2015 Jan 1;8(1):1-16. https://doi.org/10.1242/dmm.017400

[21] Olson CA, Vuong HE, Yano JM, Liang QY, Nusbaum DJ, Hsiao EY. The Gut Microbiota Mediates the AntiSeizure Effects of the KD. Cell. 2018 Jun;173(7):17281741.e13. https://doi.org/10.1016/j.cell .2018 .04 .027

[22] Chung H, Pamp SJ, Hill JA, Surana NK, Edelman SM, Troy EB, et al. Gut Immune Maturation Depends on Colonization with a Host-Specific Microbiota. Cell. 2012 Jun;149(7):1578-93. https://doi.org/10.1016/j.cell .2012 .04 .037 
UNDERGRADUATE RESEARCH IN NATURAL AND CLINICAL SCIENCE AND TECHNOLOGY (URNCST) JOURNAL

Read more URNCST Journal articles and submit your own today at: https://www.urncst.com

\section{Article Information}

Managing Editor: Jeremy Y. Ng

Peer Reviewers: Siobhan O'Brien, Brad Currier

Article Dates: Received Nov 14 20; Accepted Feb 11 21; Published Apr 1621

\section{Citation}

Please cite this article as follows:

Shirdarreh M, Sadeghi Y, Rahimi T. The impact of ketogenic diet on colorectal cancer progression and the

co-evolution of gut microbiota: A research protocol. URNCST Journal. 2021 Apr 16: 5(4).

https://urncst.com/index.php/urncst/article/view/223

DOI Link: https://doi.org/10.26685/urncst.223

\section{Copyright}

(C) Melika Shirdarreh, Yasamin Sadeghi, Tina Rahimi. (2021). Published first in the Undergraduate Research in Natural and Clinical Science and Technology (URNCST) Journal. This is an open access article distributed under the terms of the Creative Commons Attribution License (https://creativecommons.org/licenses/by/4.0/), which permits unrestricted use, distribution, and reproduction in any medium, provided the original work, first published in the Undergraduate Research in Natural and Clinical Science and Technology (URNCST) Journal, is properly cited. The complete bibliographic information, a link to the original publication on http://www.urncst.com, as well as this copyright and license information must be included.
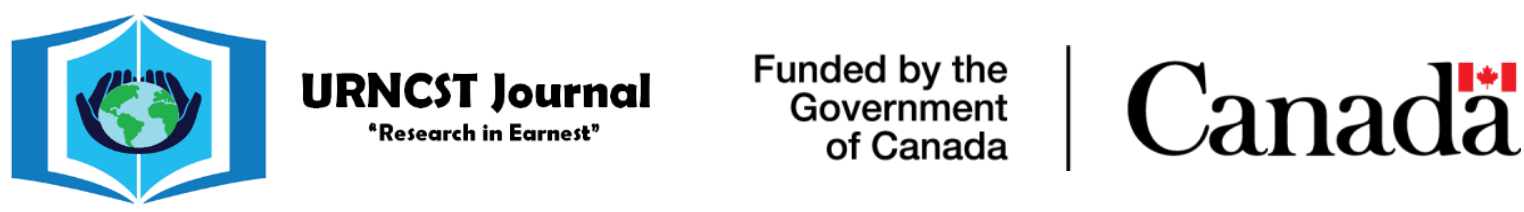

Do you research in earnest? Submit your next undergraduate research article to the URNCST Journal!

| Open Access | Peer-Reviewed | Rapid Turnaround Time | International |

| Broad and Multidisciplinary | Indexed | Innovative | Social Media Promoted |

Pre-submission inquiries? Send us an email at info@ urncst.com | Facebook, Twitter and LinkedIn: @ URNCST

Submit YOUR manuscript today at https://www.urncst.com! 